\title{
Seasonal stratospheric intrusion of ozone in the upper troposphere over India
}

\author{
S. Fadnavis, T. Chakraborty, and G. Beig \\ Indian Institute of Tropical Meteorology, Pune, India \\ Received: 2 July 2010 - Revised: 16 November 2010 - Accepted: 16 November 2010 - Published: 26 November 2010
}

\begin{abstract}
The Model for Ozone and Related chemical Tracers-2 (MOZART-2) is used to examine the evolution of pollutant $\mathrm{O}_{3}$ in the upper troposphere over the Indian region. Vertical profiles of ozone mixing ratio retrieved from Microwave Limb Sounder (MLS) aboard Earth Observing System (EOS) AURA satellite for the period 2005-2009 and Tropospheric Emission Spectrometer (TES) aboard (EOS) AURA for the period 2006-2007 has been analyzed. The satellite observations reveal the evidence of downward propagation of ozone (100-200 ppb) due to stratospheric intrusion during the winter and pre-monsoon seasons. The regular feature of enhancement of ozone in the upper troposphere over India is presented. Results obtained by the MOZART-2 simulations (for years 2000-2005) confirm the observations and indicate stratospheric intrusion of $\mathrm{O}_{3}$ during winter and pre-monsoon seasons. Observed enhanced $\mathrm{O}_{3}$ mixing ratio in the upper troposphere is explained by, variation of Potential Vorticity (PV), tropopause pressure, relative humidity and $\mathrm{CO}-\mathrm{O}_{3}$ correlation.
\end{abstract}

Keywords. Atmospheric composition and structure (Middle atmosphere - composition and chemistry)

\section{Introduction}

Upper tropospheric ozone is an important greenhouse gas that affects global outgoing long wave radiations (Worden et al., 2008). Upper tropospheric ozone changes have a great impact on the surface temperature (Forster and Shine, 1997; Intergovernmental Panel on Climate Change (IPCC), 2001, 2007). The increase of tropospheric ozone since preindustrial times has produced a global-averaged radiative

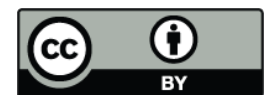

Correspondence to: S. Fadnavis (suvarna@tropmet.res.in) forcing of $0.35 \mathrm{~W} \mathrm{~m}^{-2}$ (IPCC, 2001). Positive radiative forcing of tropospheric ozone is comparable to that of halocarbons, and twice that of $\mathrm{N}_{2} \mathrm{O}$, but lower than the radiative forcing from $\mathrm{CO}_{2}$ and $\mathrm{CH}_{4}$ (IPCC, 2001, 2007). Upper tropospheric ozone enhancement would be the result of convective lifting of surface ozone, in situ production by anthropogenic $\mathrm{NO}_{\mathrm{x}}$, lightning $\mathrm{NO}_{\mathrm{x}}$ and partly by $\mathrm{HO}_{\mathrm{x}}$ radicals produced from convectively lifted formaldehyde (Cooper et al., 2008) and stratospheric intrusion. Stratosphere to troposphere transport processes are major contributors to the tropospheric ozone budget. Enhanced upper tropospheric ozone can impact air quality if it is transported to the boundary layer (Fiore et al., 2002).

The role of stratosphere-troposphere exchange in the chemical budget of ozone and other species is an important issue. During intrusion most of the trace gases transported from stratosphere spread into surrounding troposphere owing to horizontal mixing. Thus intrusion can reach down to the surface. Downward convective fluxes transport stratospheric/upper tropospheric air into the lower troposphere. An accurate knowledge of transport processes is of great importance in quantifying the roles of transport and chemistry in the budget of trace gases (Brioude et al., 2006). Austin (1991) and Follows (1992) reported that stratospheric intrusions are due to tropopause folding or the strong vertical wind shear. Baray et al. $(1998,2000)$ discussed the ozone enhancement in the upper troposphere. These studies suggest that subtropical jet stream could be the origin of tropopause folding, leading to stratospheric intrusion to the troposphere. Kim et al. (2002) studied stratospheretroposphere exchange processes over Korea. They reported that ozone intrusion in the upper troposphere corresponds to central axis of the jet stream near the tropopause. The maximum ozone by Stratosphere Troposphere Exchange (STE) occurs in winter-spring time when jet stream was located over Korea. Some of the recent studies reported STE processes over the tropics (Ricaud et al., 2007; Leclair de

Published by Copernicus Publications on behalf of the European Geosciences Union. 
Bellevue et al., 2007; Das, 2009). These studies are mostly confined to STE process during cyclone or land convection. Over the Indian region, stratosphere troposphere ozone exchange has been reported from ozonesonde, aircraft or mesosphere-stratosphere-troposphere (MST) radar, in station data for particular period (Mitra, 1996; Mandal et al., 1998; Sahu et al., 2009; Gupta et al., 2007; Kumar and Uma, 2009). Impact of transport on distribution of ozone and related trace gases over the Bay of Bengal is reported by Lal et al. (2007). However, seasonal occurrence of STE over India is not reported yet. Intra-decadal variation of stratosphere troposphere exchange of water vapor over the Tibetan plateau is reported by RuiFen and JianPing (2008).

This paper reports seasonal enhanced ozone in the upper troposphere over the Indian region due to stratospheric intrusion. For this purpose, the vertical profiles of ozone mixing ratio obtained from two satellites (1) Microwave Limb Sounder (MLS) for the period 2005-2009, (2) Tropospheric Emission Spectrometer (TES) for the period 2006-2007 over the India region $\left(5-40^{\circ} \mathrm{N}, 65-100^{\circ} \mathrm{E}\right)$ are analyzed. We use the global chemistry transport model the MOZART-2 simulations (for the years 2000-2005) to understand transport processes responsible for observed ozone enhancement over the Indian region. Simultaneously $\mathrm{CO}-\mathrm{O}_{3}$ correlation and variation in meteorological parameters such as National Centers for Environmental Prediction (NCEP) tropopause pressure, relative humidity variation and Potential Vorticity (PV) obtained from the European Centre for Medium Range Weather Forecasts (ECMWF) analysis are also examined to explain the observed feature. NCEP determines tropopause from lapse rate. The model used in the NCEP reanalysis has 28 vertical levels extending from the surface to $\sim 40 \mathrm{~km}$, with vertical resolution of $\sim 2 \mathrm{~km}$ near the tropical tropopause and $\sim 1.5 \mathrm{~km}$ near the subtropical tropopause. The NCEP output includes global analyses of tropopause temperature and pressure, which are derived from temperature analyses on model sigma levels. The tropopause pressure level is defined by the standard lapse rate criterion; that is, it is identified by the lowest level (above $450 \mathrm{mbar}$ ) where the temperature lapse rate becomes less than $2 \mathrm{~K} \mathrm{~km}^{-1}$; it is not allowed to be higher than 85 mbar. The tropopause pressure is estimated by deriving the lapse rate at each model sigma level and estimating (by interpolation in height) the pressure where the threshold value of $2 \mathrm{~K} \mathrm{~km}^{-1}$ is reached. Analyzed temperatures are then interpolated to this level. This algorithm produces tropopause estimates which vary smoothly in space and time (Randel et al., 2000).

\section{Model and data analysis}

\subsection{Model description}

The Model for Ozone and Related chemical Tracers-2 (MOZART-2) is a global chemical transport model of at- mospheric composition designed to simulate tropospheric chemical and transport processes. It has a resolution of $\sim 1.8$ degrees in longitude and latitude, and includes 31 vertical levels from the surface to the pressure level of approximately $10 \mathrm{mb}$. This model resolution allows for a description of patterns that extend over typically $200 \mathrm{~km}$, but is too coarse to provide information on smaller scale features. MOZART-2 is driven by assimilated meteorological data corresponding to years 2000-2005 from the European Center for Medium Range Weather Forecasts (ECMWF). The model accounts for the distribution of 63 chemical species subject to 168 reactions including 33 photolysis reactions. The emissions due to fossil fuel combustion, agricultural burning, bio-fuel, etc. are taken from the recent estimates for the Indian region (Beig and Brasseur, 2006) where as rest of the world, it is adopted from the growth pattern based on POET inventory (Granier et al., POET, a database of surface emissions of ozone precursors, 2000-2005, available at http://accent.aero.jussieu.fr/POET.php). Since emission inventory over the Indian region is available until 2005 only, the model simulation presented in the present work corresponds to the years 2000-2005.

\subsection{Satellite data sets}

\subsubsection{Microwave Limb Sounder (MLS) data}

The Aura Microwave Limb Sounder (MLS) aboard Earth Observing System (EOS) is one of four instruments on the NASA's EOS Aura satellite, launched on 15 July 2004. The Aura orbit is sun-synchronous at $705 \mathrm{~km}$ altitude with 98 inclinations (Waters et al., 2006). EOS MLS version 2, level 2 data are used in the present study. In the UTLS region the MLS V2.2 $\mathrm{O}_{3}$ data are less sensitive to contamination from cloud effects (Livesey et al., 2007). Vertical resolution is $\sim 4 \mathrm{~km}$ in the UTLS region. MLS ozone data quality is good at the altitudes above $215 \mathrm{mb}$ pressure level. For ozone data points having negative 2 GPprecision values are not taken into consideration. MLS ozone mixing ratio data are obtained from the website http://disc.gsfc.nasa.gov/data/ datapool/MLS.

In the present study MLS ozone data are averaged over the Indian region $\left(5^{\circ} \mathrm{N}\right.$ to $40^{\circ} \mathrm{N}$ and $65^{\circ} \mathrm{E}$ to $\left.100^{\circ} \mathrm{E}\right)$. The area averaged ozone are computed for August 2004 to June 2009 between $215-68 \mathrm{mb}(215,146,100,68)$. The daily area averaged mixing ratios are then averaged for a month. Monthly mean profiles are plotted to study seasonal variations within the upper troposphere and lower stratosphere.

\subsubsection{Tropospheric Emission Spectrometer (TES) data}

The Tropospheric Emission Spectrometer (TES) launched into sun-synchronous orbit aboard Aura, the third of NASA's Earth Observing System (EOS) spacecraft, on 15 July 2004. TES provides a global view of tropospheric trace gas profiles 
including ozone, water vapor, and carbon monoxide, along with atmospheric temperature, surface temperature and emissivity, effective cloud top pressure, and effective cloud optical depth (Worden et al., 2004). For cloud free conditions, the vertical resolution of TES ozone profile retrievals is typically $6 \mathrm{~km}$ in the tropics (Jourdain et al., 2007; Worden et al., 2004). TES measurements are available since 2005. TES Level 2 data with grid spacing $4^{\circ}$ longitude $\times 2^{\circ}$ latitude is analyzed in the present study. Tropospheric ozone retrievals from TES have been validated against ozonesonde and lidar measurements and it is generally found that the values are biased high by as much as $15 \%$ after accounting for the TES vertical resolution and a priori constraint (Worden et al., 2009). TES monthly mean ozone mixing ratios are obtained from the website: ftp://14ft101.larc.nasa.gov/TES/TL2O3N. 003.

The TES data is not available for some months during 2005 and 2008; hence the analysis presented here uses TES data during the years 2006 and 2007. Monthly mean profiles are plotted to study seasonal variations within the troposphere and the lower stratosphere.

The horizontal and vertical distributions of ozone are analyzed using TES and MOZART model simulations. Relative Humidity (RH) and tropopause pressure are obtained from NCEP/NCAR reanalysis data. Potential vorticity is obtained from ECMWF analysis. The potential vorticity is expressed in PV units $\left(\mathrm{m}^{2} \mathrm{~s}^{-1} \mathrm{~K} \mathrm{~kg}^{-1}\right)$. One potential vorticity unit (1 PVU) is taken as $1.0 \times 10^{-6} \mathrm{~m}^{2} \mathrm{~s}^{-1} \mathrm{~K} \mathrm{~kg}^{-1}$. Air with potential vorticity of $2 \mathrm{PVU}$ or more is taken to be of stratospheric origin (Holton et al., 1995; Newell et al., 1997). In the discussion that follows, seasons are considered as pre monsoon (March-April-May), summer monsoon (June-July-August-September) and winter (DecemberJanuary-February).

\section{Results and discussions}

Figure 1a exhibits vertical distributions of monthly mean ozone mixing ratios (averaged over the Indian region) as obtained from MLS satellite data during August 2004 to June 2009. The thick black line with dots indicates the tropopause pressure. In the upper troposphere and lower stratosphere ozone mixing ratio varies from $100-800 \mathrm{ppb}$. The most evident feature is that every year there are enhanced values of ozone in the upper troposphere during February-MarchApril. During majority of years there is ozone enhancement in the upper troposphere with mixing ratios $\sim 200 \mathrm{ppb}$ during February. Ozone mixing ratio $\sim 100 \mathrm{ppb}$ is observed near $200 \mathrm{mb}$ during the months of February-March-April of every year. During winter season tropopause is at lower altitudes (tropopause pressure $\sim 120-130 \mathrm{mb}$ ). Low tropopause pressure forms favorable condition for STE process (Das et al., 2009). Hence stratospheric ozone mixing ratio may cross tropopause and enter upper troposphere.

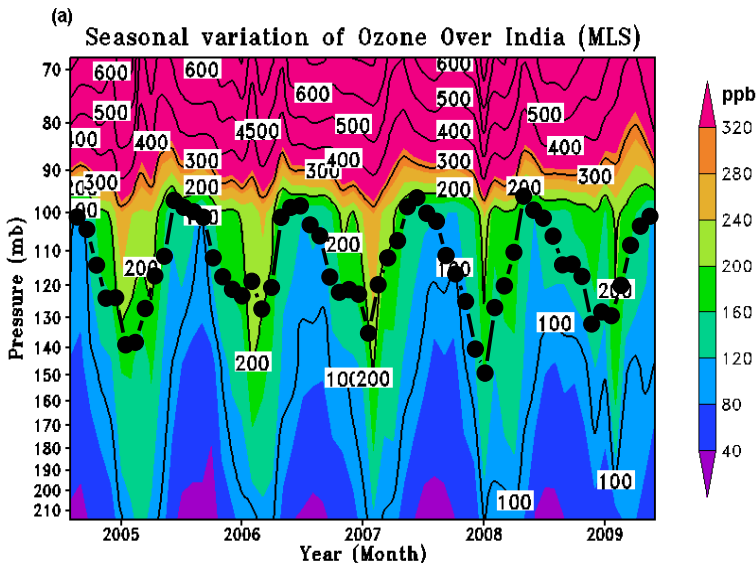

(b) Seasonal variation of Ozone Over India (TES)
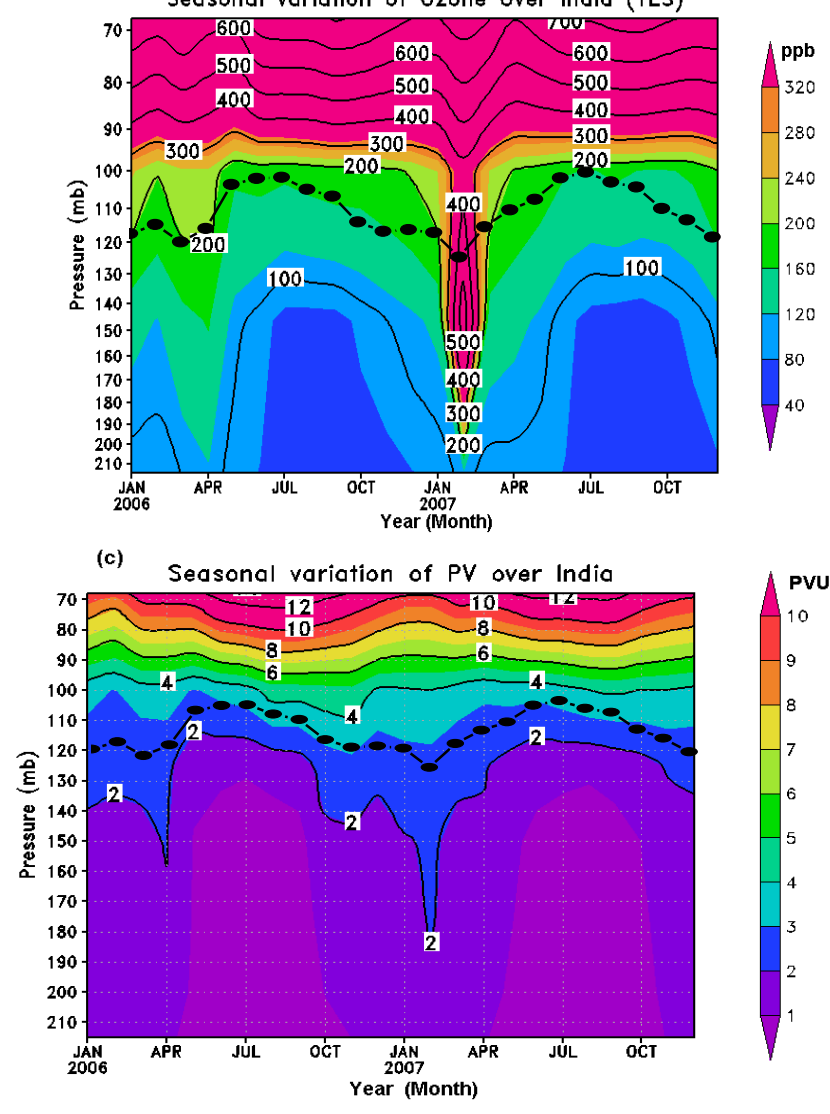

Fig. 1. (a) Vertical variation of monthly mean ozone mixing ratio (averaged over the Indian region) in the upper troposphere as obtained from MLS satellite data during August 2004 to June 2009. (b) Vertical variation of ozone mixing ratio (averaged over the Indian region) in the upper troposphere as obtained from TES satellite measurements during 2006-2007. (c) Vertical variation of potential vorticity (averaged over the Indian region) in the upper troposphere as obtained from ECMWF analyses during 2006-2007. Thick black line with dots indicates tropopause pressure. 


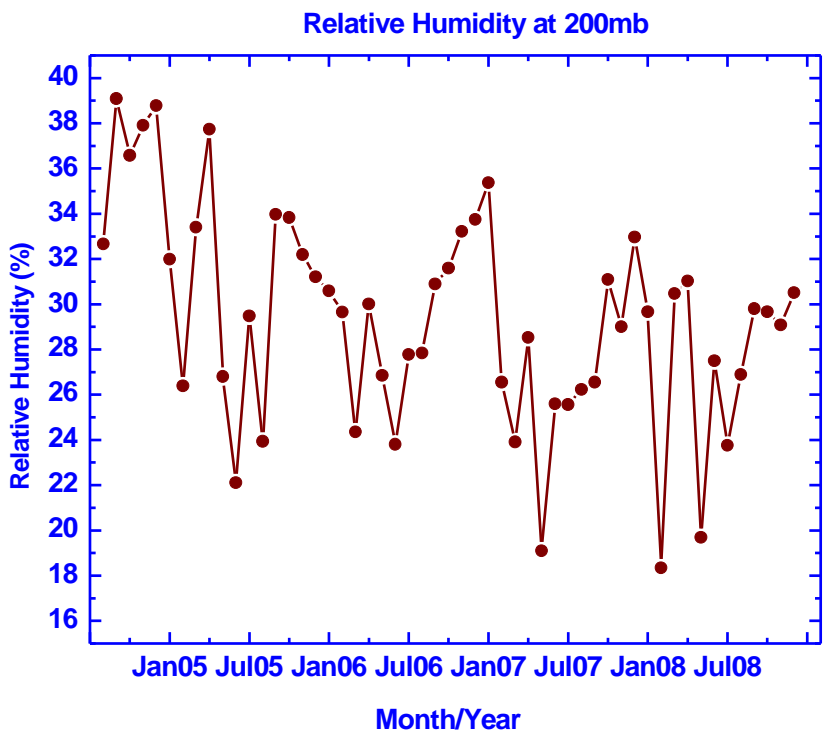

Fig. 2. Variation of relative humidity obtained from NCEP/NCAR reanalysis data at $200 \mathrm{mb}$ during August 2004-June 2009.

Figure $1 \mathrm{~b}$ shows seasonal variation of ozone in the upper troposphere as obtained from TES satellite data during 20062007. Thick black line with dots indicates tropopause pressure variation. Similar to MLS satellite observations, TES data also shows enhanced ozone mixing ratios $\sim 200 \mathrm{ppb}$ in the upper troposphere during every February. Ozone mixing ratios are seems to be propagating downward. It may crosses the tropopause and reaches to $160-180 \mathrm{mb}$ pressure levels. Ozone mixing ratios $\sim 100 \mathrm{ppb}$ are observed near $200 \mathrm{mb}$ during February-March-April. It should be noted that both MLS and TES observations show greater ozone enhancement in the upper troposphere (may be due to intrusion) during the month of February during 2006-2007.

Figure 1c depicts vertical variation of potential vorticity obtained from ECMWF analysis (averaged over the Indian region) during 2006-2007 with tropopause pressure over plotted (The thick black line with dots). It indicates that $\mathrm{PV}$ more that $2 \mathrm{PVU}$ is observed near the upper troposphere throughout the year. But, most noticeable feature is that, tongue of air with PV more than $2 \mathrm{PVU}$ penetrates into the upper troposphere up to $160-180 \mathrm{mb}$ pressure levels during every winter and pre-monsoon seasons. During 2007 it penetrates into the upper troposphere near the pressure level $\sim 145 \mathrm{mb}$ during post-monsoon season too. These pressure levels coincide with observed enhanced ozone mixing ratios in the upper troposphere during same seasons. It is interesting to compare vertical variation of PV (Fig. 1c)and ozone mixing ratio (Fig. 1b) during 2006 and 2007. PV equal to 2 PVU penetrates into the upper troposphere and reached to $160 \mathrm{mb}$ during April 2006 and $180 \mathrm{mb}$ during February 2007. Enhanced ozone mixing ratio $\geq 200 \mathrm{ppb}$ is observed at these pressure levels during same the period. This indicates that ozone mixing ratios at upper tropospheric pressure levels has its origin in the stratosphere.

Figure 2 indicates variation of NECP derived Relative $\mathrm{Hu}-$ midity (RH) at $200 \mathrm{mb}$. At this pressure level RH varies between 16\%-38\%. During February-March-April, especially during February RH near $200 \mathrm{mb}$ is very low $(<25 \%)$. Enhanced ozone mixing ratio in correlation with very low RH also indicates dry air arrived near $200 \mathrm{mb}$ may be of stratospheric origin. Over Europe, Tulet et al. (2002) also observed ozone mixing ratio $\sim 110 \mathrm{ppb}$ between $500-300 \mathrm{mb}$ with low RH (20-40\%) during stratospheric intrusion. Hence, observed enhanced ozone mixing ratio ( $\sim 100 \mathrm{ppb})$ near $200 \mathrm{mb}$ level may be due to stratospheric intrusion. To identify stratospheric intrusion across the tropical tropopause, we also used the correlation between $\mathrm{CO}$ and ozone. Waugh et al. (1997) introduced the concept for tracers $\left(\mathrm{N}_{2} \mathrm{O}\right.$ versus $\mathrm{NO}_{\mathrm{y}}$ ) correlation to investigate tropospheric transport. They used the concept of mixing lines to identify cross tropopause mixing. Hoor et al. (2002) and Hipskind et al. (1987) used the correlation between $\mathrm{CO}$ and ozone to identify exchange across extra-tropical tropopause. Hoor et al. (2002) explained that if we neglect mixing processes across the tropopause, the idealized relationship between ozone and $\mathrm{CO}$ can be expected to display L-shape (Fischer et al., 2000). The nearly constant stratospheric equilibrium values of $\mathrm{CO}$ at strongly increasing ozone gives rise to a stratospheric branch, whereas the tropospheric branch is characterized by low ozone but highly variable $\mathrm{CO}$ values ranging from 50-200 ppb. In order to confirm the stratospheric intrusion correlation is studied from TES satellite observed $\mathrm{CO}$ and $\mathrm{O}_{3}$ at upper tropospheric pressure levels during February-April 2007. Correlation plots are obtained from time series of monthly mean ozone and $\mathrm{CO}$ mixing ratio averaged over the Indian region. Figure $3 a-j$ indicates TES ozone and CO mixing ratio correlation plot at 215, 146, and $100 \mathrm{mb}$ level during February, March and April 2007, respectively. The L-shape curves at these pressure levels show high ozone $\left(\mathrm{O}_{3}>350 \mathrm{ppb}\right)$ mixing ratios indicate stratospheric branch. Strong negative correlation varying between -0.93 and -0.87 is observed at upper tropospheric pressure levels. The opposite gradients of the two species indicate the ozone toward the stratospheric air and the carbon monoxide toward the tropospheric air. During tropopause fold event Hipskind et al. (1987) also reported negative correlation between $\mathrm{O}_{3}$ and $\mathrm{CO}$ (ranging between -0.98 and -0.54 ).

To examine transport path ways, we use MOZART-II simulations for the years 2000-2005. Figure 4a-f shows seasonal variation of ozone mixing ratios between $1000 \mathrm{mb}$ to $68 \mathrm{mb}$ as obtained from MOZART model simulations for years 2005-2000, respectively. Thick black color dotted line indicates tropopause pressure. The model simulations show an ozone seasonal cycle which is consistent with the observed intrusion of stratospheric air into the upper troposphere at the beginning of the year. Every year there is strong ozone enhancement in the upper troposphere during 
(a)
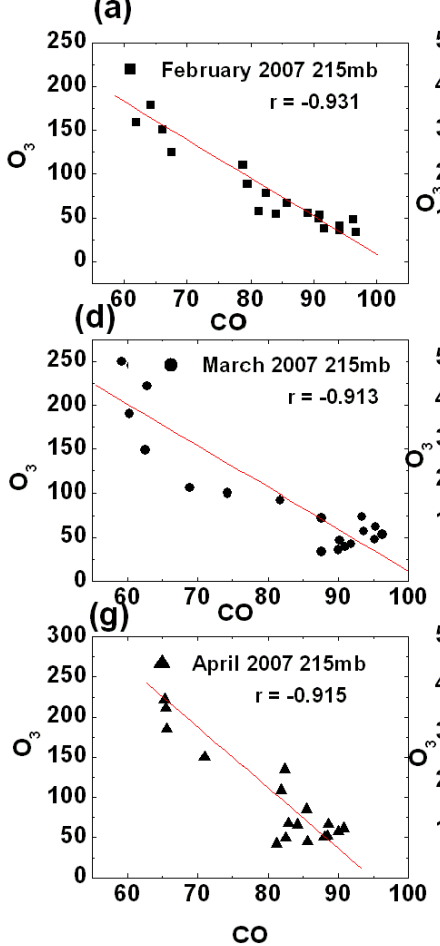

(b)

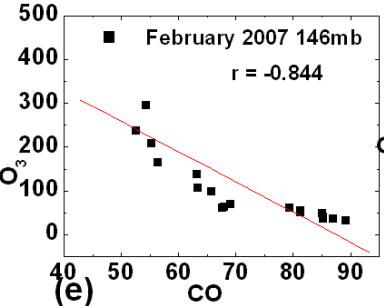

(c)

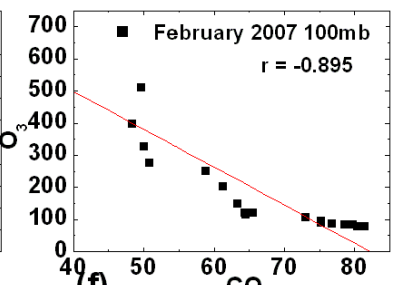

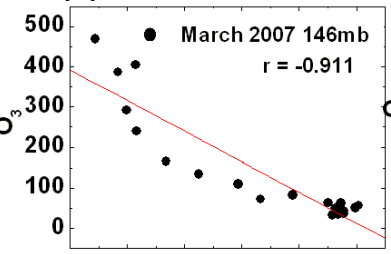

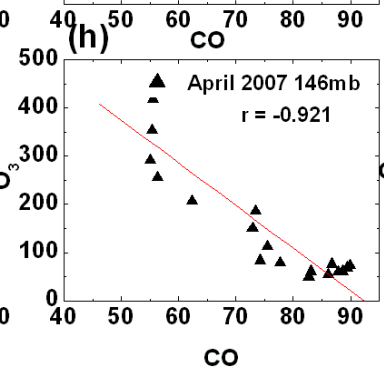

Fig. 3. Correlation between TES ozone and CO volume mixing ratio during (a) February 2007 at 215 mb, (b) February 2007 at $146 \mathrm{mb}$, (c) February 2007 at $100 \mathrm{mb}$, (d) March 2007 at $215 \mathrm{mb}$, (e) March 2007 at $146 \mathrm{mb}$, (f) March 2007 at 100 mb, (g) April 2007 at $215 \mathrm{mb}$, (h) April 2007 at $146 \mathrm{mb}$, (i) April 2007 at $100 \mathrm{mb}$.

winter and pre-monsoon seasons (except during 2005; where intrusion may be weaker). Ozone mixing ratio $\sim 200 \mathrm{ppb}$ crosses the tropopause and enters the upper troposphere during February-April as observed in MLS and TES data. During winter and pre-monsoon seasons of the years 2004-2000, ozone mixing ratio $\sim 100 \mathrm{ppb}$ reaches to $300 \mathrm{mb}$. Thus model simulations also show downward transport of ozone mixing ratios during winter and pre-monsoon seasons as observed in satellite measurements.

Since ozone intrusion mainly occurs during FebruaryMarch-April months, ozone mixing ratios are averaged over these months at every pressure level. These seasonally averaged ozone mixing ratios are then averaged over the Indian longitudes $\left(65-100^{\circ} \mathrm{E}\right)$. The latitude-altitude distribution of zonal and seasonal (February-March-April) averaged ozone mixing ratios as obtained from TES measurements for the year 2007 and model simulation for the years 2002-2005 is shown in Fig. 5a-e. These figures indicate that ozone intrusion occur between $20-40^{\circ} \mathrm{N}$ latitudes. Ozone mixing ratio $\sim 400 \mathrm{ppb}$ reaches up to $170 \mathrm{mb}$ and $200 \mathrm{ppb}$ near $300 \mathrm{mb}$ at $35^{\circ} \mathrm{N}$. Between the latitudes $20^{\circ} \mathrm{N}$ and $30^{\circ} \mathrm{N}$ ozone mixing ratio $\sim 100-200 \mathrm{ppb}$ reaches to $215 \mathrm{mb}$ pressure level. Similar results are observed in model simulation of the years 2001-2000 (figures not included). Latitude-altitude cross section of ozone mixing ratio variation during 2005 (Fig. 5b) shows that ozone mixing ratio $\sim 300-400 \mathrm{ppb}$ enters the tro- posphere (at the altitudes below $100 \mathrm{mb}$ ) over the narrow region $32-40^{\circ} \mathrm{N}$. This may be the reason that seasonal variation of ozone show weaker intrusion (as observed in Fig. 4a) during 2005. Figure $5 \mathrm{f}$ shows latitude-altitude cross-section of PV. PV more than 2 PVU is observed between latitudes $20^{\circ} \mathrm{N}$ and $40^{\circ} \mathrm{N}$, at the pressure levels above $100-120 \mathrm{mb}$. This confirms that the ozone intrusion might have occurred between $20^{\circ} \mathrm{N}$ and $40^{\circ} \mathrm{N}$ as seen in observational data and model simulated results.

Latitude-longitude cross-section of ozone distribution (averaged for February-March-April months) as obtained from TES observations and model simulations is examined at every upper tropospheric pressure level between $216 \mathrm{mb}$ and $100 \mathrm{mb}$. Figure $6 \mathrm{a}-\mathrm{d}$ depicts the horizontal distribution of seasonally averaged (February-March-April) ozone at $146 \mathrm{mb}$ and $215 \mathrm{mb}$ pressure levels as obtained from TES observations for the year 2007 (Fig. 6a-b) and model simulations for the year 2005 (Fig. 6c-d). Figure 6a shows that enhanced ozone mixing ratio is observed in the region with latitudes $30-36^{\circ} \mathrm{N}$ and longitudes $85-95^{\circ} \mathrm{E}$. Ozone intrusion at $146 \mathrm{mb}$ level may be occurring keeping center within this region. Ozone mixing ratio $\sim 600 \mathrm{ppb}$ is observed in the location near the point $33^{\circ} \mathrm{N}, 93^{\circ} \mathrm{E}$. In the region between the latitudes $30-40^{\circ} \mathrm{N}$ (over all the longitudes) ozone mixing ratios varies between 200-600 ppb. Similar structure of ozone distribution (but enhanced ozone mixing ratio) is observed 

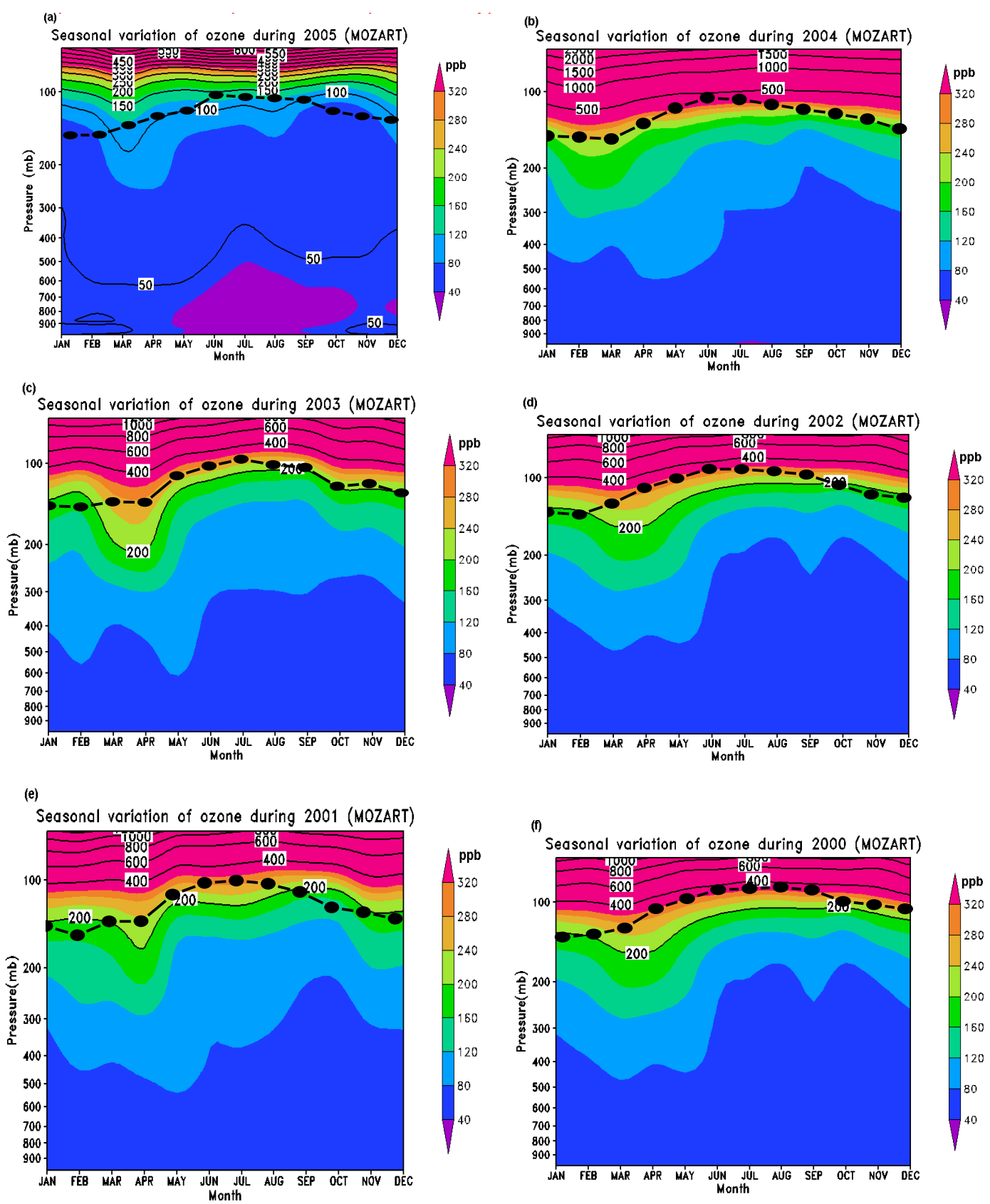

Fig. 4. Vertical variation of ozone mixing ratio (averaged over the Indian region) as obtained from analysis of MOZART model simulations for the years (a) 2005, (b) 2004, (c) 2003, (d) 2002, (e) 2001, (f) 2000. Thick black line with dots indicates tropopause pressure.

at $100 \mathrm{mb}$ (figure not shown). Figure $6 \mathrm{~b}$ exhibits the horizontal distribution of ozone at $215 \mathrm{mb}$ pressure level. Enhanced ozone mixing ratio $\sim 200-300 \mathrm{ppb}$ is observed in the region with latitudes $30-36^{\circ} \mathrm{N}$ and longitudes $85-95^{\circ} \mathrm{E}$. At $316 \mathrm{mb}$ pressure level (figure not shown) ozone mixing ratio $\sim 100 \mathrm{ppb}$ is observed in the same region (latitudes $30-36^{\circ} \mathrm{N}$ and longitudes $85-95^{\circ} \mathrm{E}$ ) and $70-100 \mathrm{ppb}$ between $30-40^{\circ} \mathrm{N}$ (over all the longitudes). Figure $6 \mathrm{c}$ and d depicts ozone distribution (seasonally averaged) at $146 \mathrm{mb}$ and $215 \mathrm{mb}$ pres- sure levels as obtained from model simulation for the year 2005. MOZART model simulation does not indicate very high ozone mixing ratio in the region with latitudes $30-36^{\circ} \mathrm{N}$ and longitudes $85-95^{\circ} \mathrm{E}$ as observed in TES satellite data. This may be due to coarse model resolution $\sim 1.8$ degrees in longitude and latitude. At $146 \mathrm{mb}$, ozone mixing ratio $\sim 150-400$ ppb (Fig. 6c) and at $215 \mathrm{mb}$ ozone mixing ratio $\sim 100-150 \mathrm{ppb}$ are observed between the latitudes $30-40^{\circ} \mathrm{N}$ which is in agreement with TES observations. Figure 6e 

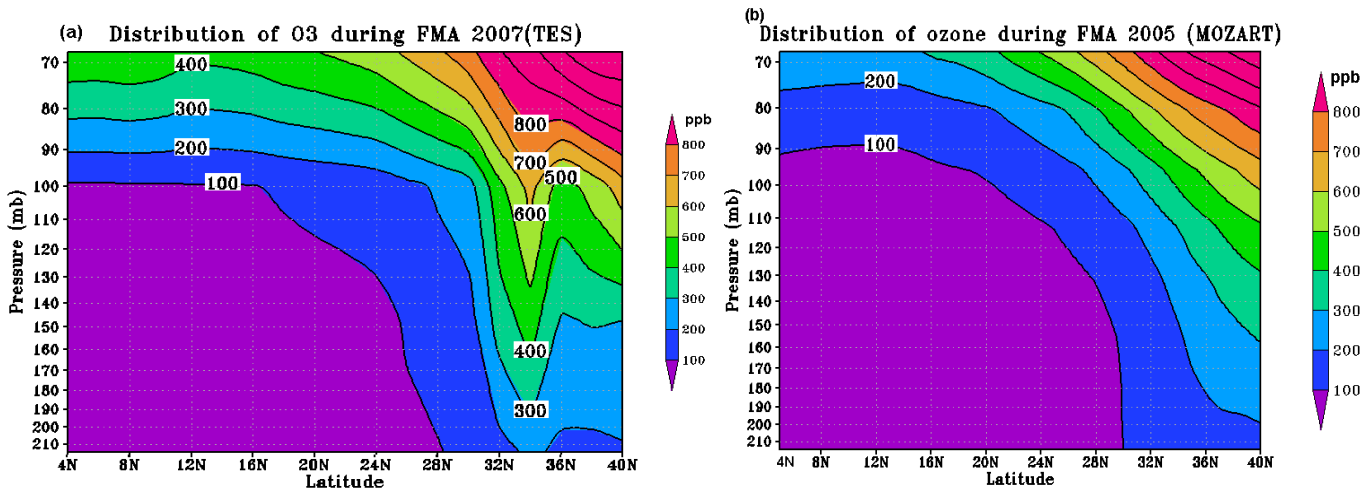

(c) Distribution of ozone during FMA 2004 (MOZART)
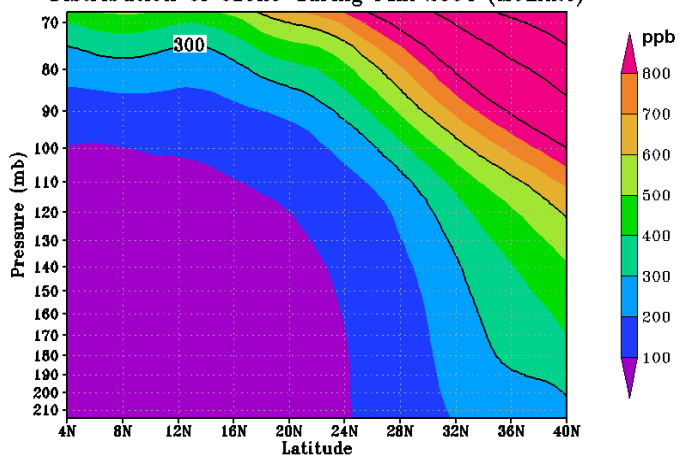

(d) Distribution of ozone during FMA 2003 (MOZART)
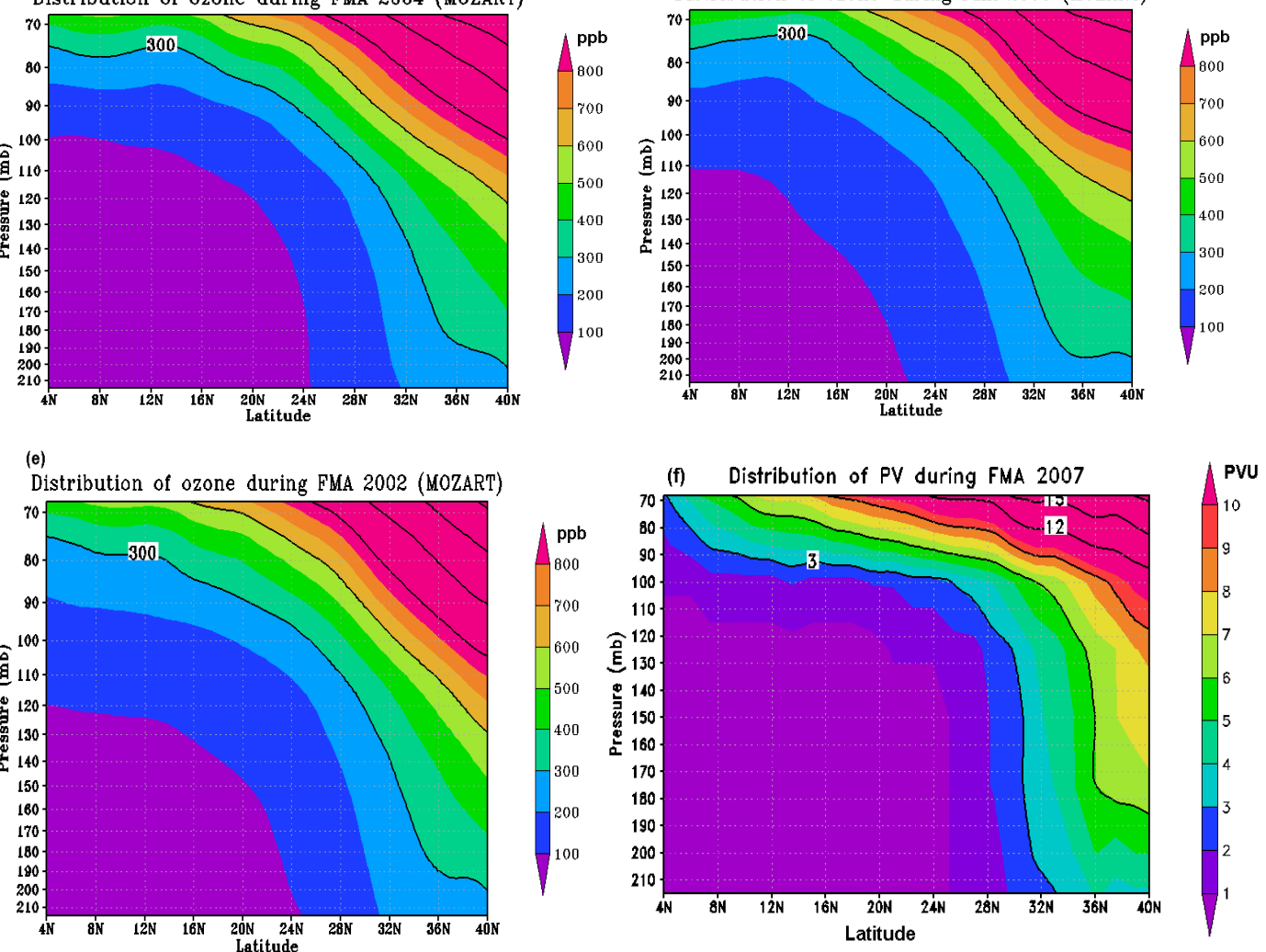

Fig. 5. Latitude-height cross section of zonal (averaged over the longitudes $65-100^{\circ}$ E) and seasonal (February-March-April months) mean ozone mixing ratio as obtained from (a) analysis of TES observations for the year 2007; (b) analysis of MOZART model simulation for the year 2005; (c) analysis of MOZART model simulation for the year 2004; (d) analysis of MOZART model simulation for the year 2003; (e) analysis of MOZART model simulation for the year 2002; (f) latitude-height cross section of zonal (averaged over the longitudes $65-100^{\circ} \mathrm{E}$ ) and seasonal (February-March-April months) mean potential vorticity for the year 2007.

and $f$ exhibits spatial distribution of zonal (longitudes $65^{\circ} \mathrm{E}-$ $100^{\circ} \mathrm{E}$ ) and seasonal (FMA) averaged potential vorticity at $146 \mathrm{mb}$ and $215 \mathrm{mb}$ pressure levels respectively. PV more than 2 PVU is observed between the latitudes $28^{\circ} \mathrm{N}$ and $40^{\circ} \mathrm{N}$ at $146 \mathrm{mb}$ and $215 \mathrm{mb}$ pressure levels. This indicates that enhance ozone mixing ratios observed from TES measurements and model simulation at these latitudes and altitudes are of stratospheric origin. From ozonesonde observations Kim et al. (2002) showed that stratospheric ozone is transported down to the upper troposphere by strong zonal wind speed of upper level jet stream. The enhancement of ozone mixing ratio in the troposphere occurs during winter spring time over Korea. It should be noted that during winter location of East Asian Subtropical Westerly Jet (EASWJ) near $200 \mathrm{mb}$ is generally along $28^{\circ} \mathrm{N}, 90^{\circ} \mathrm{E}$ and pre-monsoon season (April-May) it jumps to nearby $32^{\circ} \mathrm{N}$ and migrates northward to $40^{\circ} \mathrm{N}$ (Zhang et al., 2008). Thus enhanced ozone mixing ratios in the upper troposphere as 
(a)

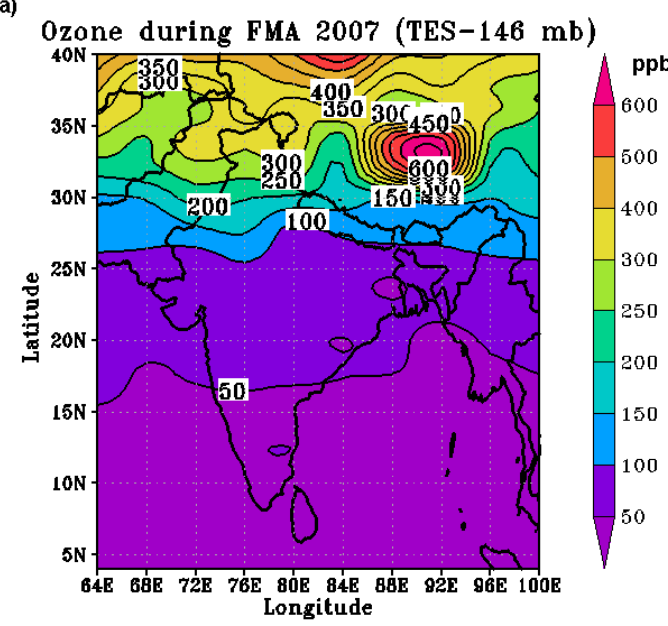

(c)
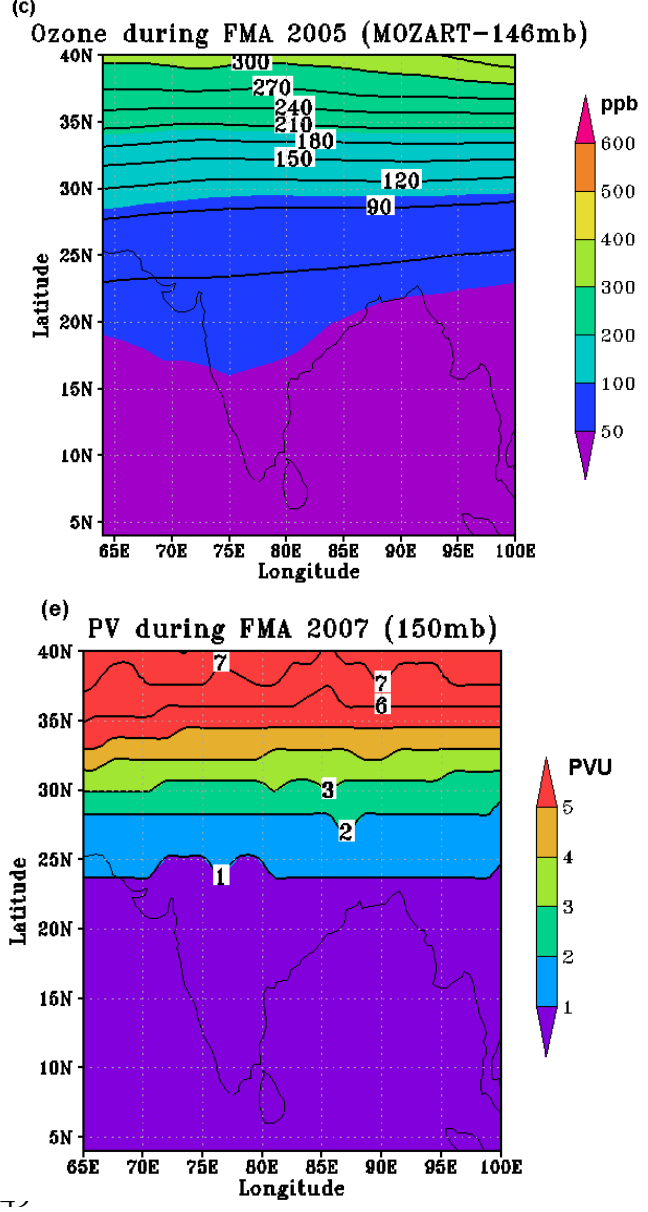

(b)

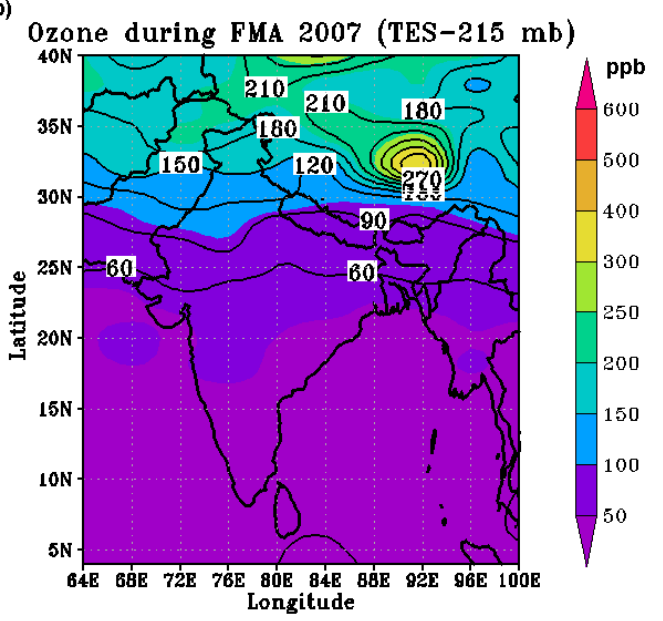

(d) Ozone during FMA 2005 (MOZART-215mb)
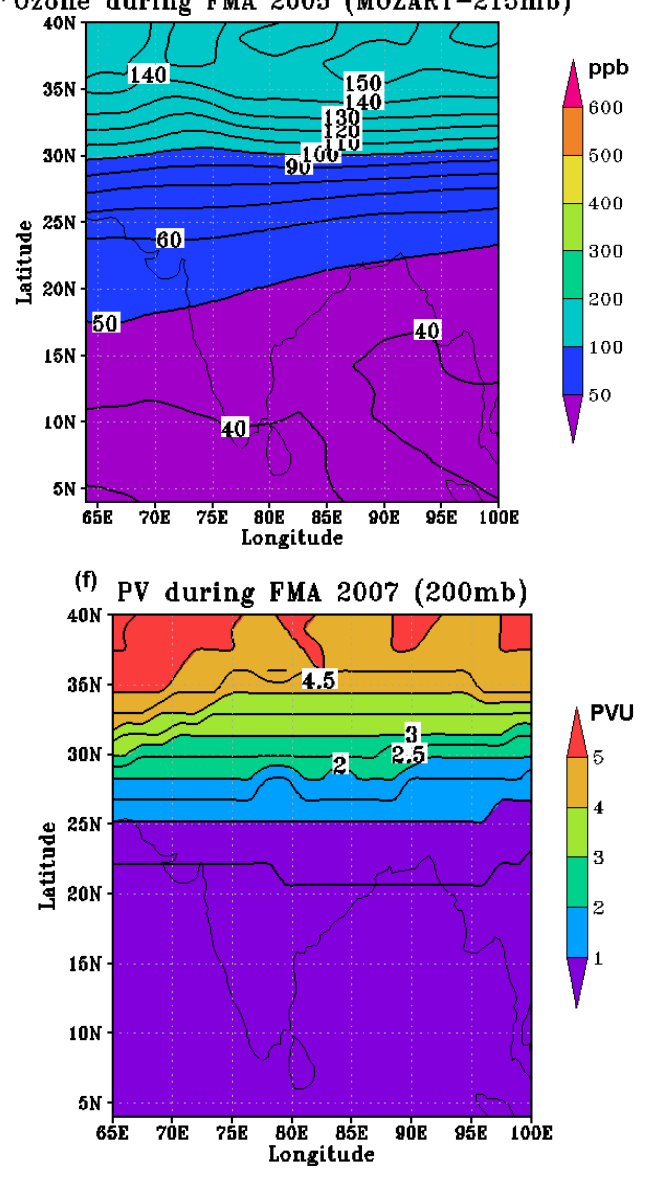

Fig. 6. Latitude-longitude distribution of seasonal averaged ozone (averaged for February-March-April months) over the Indian region (a) at $146 \mathrm{mb}$ as obtained from TES measurements for the year 2007; (b) at $215 \mathrm{mb}$ as obtained from TES measurements for the year 2007; (c) at $146 \mathrm{mb}$ as obtained from MOZART model simulation for the year 2005; (d) at $215 \mathrm{mb}$ as obtained from MOZART model simulation for the year 2005; (e) latitude-longitude cross-section of seasonal averaged (February-March-April) potential vorticity at $150 \mathrm{mb}$; (f) latitudelongitude cross-section of seasonal averaged (February-March-April) potential vorticity at $200 \mathrm{mb}$. 
observed in satellite data (over the latitudes $20-40^{\circ} \mathrm{N}$ ) and model simulations during winter and pre-monsoon seasons may be due to downward transport of ozone from stratosphere due to strong zonal wind speed of the EASWJ. It should be noted that the intense thunderstorm activity during pre-monsoon season also contributes in photochemical production of ozone (via production of $\mathrm{NO}_{\mathrm{x}}$ ) in the upper troposphere.

\section{Discussions on transport mechanism}

MLS and TES observations show the evidence of enhanced ozone mixing ratios in the upper troposphere due to downward propagation of ozone mixing ratio ( $\sim 200 \mathrm{ppb})$ from the lower stratosphere to the upper troposphere (up to $200 \mathrm{mb}$ ) during winter and pre-monsoon seasons when tropopause is at lower altitudes. PV shows PV $\geq 2$ PVU during these seasons. This indicates tongue of stratospheric air enters the upper troposphere during winter and pre-monsoon seasons. Low relative humidity $(<25 \%)$ near $200 \mathrm{mb}$ confirms that air mass near $215-100 \mathrm{mb}$ pressure levels is of stratospheric origin. Stratospheric intrusion is also identified using $\mathrm{CO}-\mathrm{O}_{3}$ correlation. Strong negative correlation coefficients and Lshape of $\mathrm{CO}-\mathrm{O}_{3}$ correlation plots at the upper tropospheric pressure levels confirm the stratospheric intrusion.

Latitude-height cross section shows that ozone intrusion occurs between the latitudes $20^{\circ} \mathrm{N}$ and $40^{\circ} \mathrm{N}$. Horizontal distribution of TES ozone mixing ratio (seasonally averaged during February-March-April 2007) indicates that center of intrusion might have been over Indian subtropical region (latitudes $30-36^{\circ} \mathrm{N}$ and longitudes $85-95^{\circ} \mathrm{E}$ ) during 2007. MOZART model simulation has also reproduced ozone intrusion over the Indian subtropical region during winter and pre-monsoon seasons. Latitude-altitude and latitude-longitude cross-sections of PV show PV $\geq 2$ PVU between $20^{\circ} \mathrm{N}$ and $40^{\circ} \mathrm{N}$ during these seasons. During winter and pre-monsoon seasons, East Asian subtropical westerly jet (near $200 \mathrm{mb}$ ) blow near these latitudes. Downward ozone transport by the strong zonal wind speed of the jet stream may be responsible for stratospheric intrusion. From Tropospheric Emission Spectrometer (TES) measurements, Worden et al. (2009) also observed enhanced ozone mixing ( $200 \mathrm{ppb})$ near $300 \mathrm{mb}$ related to stratospheric intrusion during pre-monsoon season over the Indian region. Sprenger and Wernli (2003) examined 15 years of ERA 15 meteorological data from ECMWF and found stratosphere to troposphere exchange is maximum over central Asia in the premonsoon season.

Hence it is proposed that downward propagation of ozone from the lower stratosphere into the upper troposphere during winter pre-monsoon seasons contributes to ozone enhancement in the upper troposphere over the Indian region. Downward ozone transport by the strong zonal wind speed of the jet stream may be responsible for stratospheric intrusion.

\section{Conclusions}

The vertical profiles of ozone mixing ratio retrieved from Microwave Limb Sounder (MLS) during 2004-2009 and Tropospheric Emission Spectrometer (TES) for the period 20062007 show evidence of enhanced ozone mixing ratio in the upper troposphere during winter and pre-monsoon. Seasonal distribution of potential vorticity shows PV greater than $2 \mathrm{PVU}$ in the upper troposphere during these seasons. This indicates that observed enhanced ozone mixing ratios in the upper troposphere may be due to downward propagation of $\mathrm{O}_{3}(100-200 \mathrm{ppb})$ from the lower stratosphere to the upper troposphere. Simultaneously very low RH $(>25 \%)$ and strong negative $\mathrm{CO} / \mathrm{O}_{3}$ correlation (in the upper troposphere) confirms that observed enhanced ozone in the upper troposphere may be due to stratospheric intrusion during winter and pre-monsoon seasons. MOZART model simulations (for the years 2000-2005) confirmed these results.

Seasonal mean latitude-height and latitude-longitude cross sections (at the upper tropospheric pressure levels) of satellite observed ozone and model simulations show that stratospheric intrusion occurs over the Indian subtropical region $\left(25-40^{\circ} \mathrm{N}\right)$. Seasonal mean latitude-height and latitudelongitude cross-sections of potential vorticity show PV more than $2 \mathrm{PVU}$ over the latitudes $25-40^{\circ} \mathrm{N}$. During winter and pre-monsoon seasons, East Asian south westerly jet (near $200 \mathrm{mb}$ ) blows over the Indian subtropical region. Downward transport of ozone by the strong zonal wind speed of the jet stream may be responsible for observed seasonal stratospheric intrusion.

Acknowledgements. We acknowledge with gratitude B. N. Goswamy, Director IITM for his encouragement during the course of this study. The authors also thank to anonymous reviewer for their critical comments and valuable suggestions, which helped in improving the scientific value of this research paper.

Topical Editor C. Jacobi thanks J.-L. Baray and another anonymous referee for their help in evaluating this paper.

\section{References}

Austin, J. F. and Follows, M. J.: The ozone record at Payerne: an assessment of the cross-tropopause flux, Atmos. Environ., 25A, 1873-1880, 1991.

Baray, J., Baray, L., Ancellet, G., Taupin, F. G., Bessafi, M., Baldy, S., and Keckhut, P.: Subtropical tropopause break as a possible stratospheric source of ozone in the tropical troposphere, J. Atmos. Solar Terr. Phys., 60(1), 27-36, 1998.

Baray, J.-L., Daniel, V., Ancellet, G., and Legras, B.: Planetaryscale tropopause folds in the southern subtropics, Geophys. Res. Lett., 27(3), 353-356, doi:10.1029/1999GL010788, 2000.

Beig, G. and Brasseur, G. P.: Influence of anthropogenic emissions on tropospheric ozone and its precursors over the Indian tropical region during a Monsoon, Geophys. Res. Lett., 33, L07808, doi:10.1029/2005GL024949, 2006. 
Brioude, J., Cammas, J.-P., and Cooper, O. R.: Stratospheretroposphere exchange in a summertime extratropical low: analysis, Atmos. Chem. Phys., 6, 2337-2353, doi:10.5194/acp-62337-2006, 2006.

Cooper, O. R.: Evidence for a recurring eastern North America upper tropospheric ozone maximum during summer, J. Geophys. Res., 112, D23304, doi:10.1029/2007JD008710, 2007.

Das, S. S.: A new perspective on MST radar observations of stratospheric intrusions into-troposphere associated with tropical cyclone, Geophys. Res. Lett., 36, L15821, doi:10.1029/2009GL039184, 2009.

Fiore, A. M., Jacob, D. J., Bey, I., Yantosca, R. M., Field, B. D., Fusco, A. C., and Wilkinson, J. G.: Background ozone over the United States in summer: Origin, trend, and contribution to pollution episodes, J. Geophys. Res., 107(D15), 4275, doi:10.1029/2001JD000982, 2002.

Fischer, H., Wienhold, F. G., Hoor, P., Bujok, O., Schiller, C., Siegmund, P., Ambaum, M., Scheeren, H. A., and Lelieveld, J.: Tracer correlations in the northern high latitude lowermost stratosphere: Influence of cross-tropopause mass exchange, Geophys. Res. Lett., 27, 97-100, 2000.

Follows, M. J.: Notes and correspondence; on the cross-tropopause exchange of air, J. Atmos. Sci., 49, 879-882, 1992.

Follows, M. J. and Austin, J. F.: A zonal average model of the stratospheric contribution to the tropospheric ozone budget, J. Geophys. Res., 97, 18047-18060, 1992.

Forster, P. M. de F. and Shine, K. P.: Radiative forcing and temperature trends from stratospheric ozone changes, J. Geophys. Res., 102, 10841-10857, 1997.

Granier, C., Guenther, A., Lamarque, J. F., Mieville, A., Muller, J. F, Olivier, J., Orlando, J., Peters, J., Petron, G., Tyndall, G., and Wallens, S.: POET, a database of surface emissions of ozone precursors, available from http://accent.aero.jussieu.fr/POET.php, last access November 2010

Gupta, S., Lal, S., Venkataramani, S., Rajesh, T. A., and Acharya, Y. B.: Variability in the vertical distribution of ozone over a subtropical site in India during a winter month, J. Atmos. Solar Terr. Phys., 69, 1502-1512, 2007.

Hipskind, R. S., Gregory, G. L., Sachse, G. W., Hill, G. F., and Danielsen, E. F.: Correlations between ozone and carbon monoxide in the lower stratosphere, folded tropopause, and maritime troposphere, J. Geophys. Res., 92, 2121-2130, 1987.

Holton, J. R., Haynes, P. H., McIntyre, M. E., Douglass, A. R., Rood, R. B., and Pfister, L.: Stratosphere-troposphere exchange, Rev. Geophys., 33(4), 403-439, doi:10.1029/95RG02097, 1995.

Hoor, P., Fischer, H., Lange, L., Lelieveld, J., and Brunner, D.: Seasonal variations of mixing layer in the lowermost stratosphere as identified by the CO-O3 correlation from in situ measurements, J. Geophys. Res., 107D(5), 4044, doi:10.1029/2000JD000289, 2002.

Intergovernmental Panel on Climate Change, Climate Change 2001: The Scientific Basis - Contribution of Working Group I to the Third Assessment Report of the Intergovernmental Panel on Climate Change, edited by: Houghton, J. T., Ding, Y., Griggs, D. J., Noguer, M., van der Linden, P. J., Dai, X., Maskell, K., and Johnson, C. A., 881 pp., Cambridge Univ. Press, New York, 2001.

Intergovernmental Panel on Climate Change, Climate Change 2007: The Physical Science Basis, Summary for Policymakers - Contribution of Working Group I to the Fourth Assessment Report of the Intergovernmental Panel on Climate Change, Cambridge Univ. Press, New York, 2007.

Jourdain, L., Worden, H. M., Worden, J. R., Bowman, K., Li, Q., Eldering, A., Kulawik, S. S., Osterman, G., Boersma, K. F., Fisher, B., Rinsland, C. P., Beer, R., and Gunson, M.: Tropospheric vertical distribution of tropical Atlantic ozone observed by TES during the northern African biomass burning season, Geophys. Res. Lett., 34, L04810, doi:10.1029/2006GL028284, 2007.

Kim, Y. K., Lee, H. W., Park, J. K., and Moon, Y. S.: The stratosphere-troposphere exchange of ozone and aerosols over Korea, Atmos. Environ., 36A, 449-436, 2002.

Kumar, K. K. and Uma, K. N.: High temporal resolution VHF radar observations of stratospheric air intrusions in to the upper troposphere during the passage of a mesoscale convective system over Gadanki (13.5 N, 79.2 ${ }^{\circ}$ E), Atmos. Chem. Phys. Discuss., 9, 13843-13857, doi:10.5194/acpd-9-13843-2009, 2009.

Lal, S., Sahu, L. K., and Venkataramani, S.: Impact of transport from the surrounding continental regions on the distributions of ozone and related trace gases over the Bay of Bengal during February 2003, J. Geophys. Res., 112, D14302, doi:10.1029/2006JD008023, 2007.

Leclair De Bellevue, J., Baray, J. L., Baldy, S., Ancellet, G., Diab, R., and Ravetta, F.: Simulations of stratospheric to tropospheric transport during the tropical cyclone Marlene event, Atmos. Environ., 41, 6510-6526, 2007.

Livesey, N. J.: Version 2.2 level 2 data quality and description document, report, NASA Goddard Earth Sci. Distribution Active Arch. Cent., Pasadena, California, 2007.

Mandal, T. K., Cho, J. Y. N., Rao, P. B., Jain, A. R., Peshin, S. K., Srivastava, S. K., Bohra, A. K., and Mitra, A. P.: Stratospheretroposphere ozone exchange observed with the Indian MST radar and a simultaneous balloon-borne ozonesonde, Rad. Sci., 33(4), 861-893, doi:10.1029/97RS03553, 1998.

Mitra, A. P.: Troposphere-stratosphere coupling and exchange at low latitude Adv. Space Res., 17(11), 89-97, 1996.

Newell, R. E., Browell, E. V., Davis, D. D., and Liu, S. C.: Western Pacific tropospheric ozone and potential vorticity: Implications for Asian pollution, Geophys. Res. Lett., 24(22), 2733-2736, doi:10.1029/97GL02799, 1997.

Randel, W. J., Wu, F., and Gaffen, D. J.: Interannual variability of the tropical tropopause derived from radiosonde data and NCEP reanalyses, J. Geophys. Res., 105(D12), 15509-15523, 2000.

Ricaud, P., Barret, B., Attié, J.-L., Motte, E., Le Flochmoën, E., Teyssèdre, H., Peuch, V.-H., Livesey, N., Lambert, A., and Pommereau, J.-P.: Impact of land convection on tropospherestratosphere exchange in the tropics, Atmos. Chem. Phys., 7, 5639-5657, doi:10.5194/acp-7-5639-2007, 2007.

RuiFen, Z. and Li JianPing: Influence of atmospheric heat sources over the Tibetan Plateau and the tropical western North Pacific on the inter-decadal variations of the stratosphere troposphere exchange of water vapor, Science in China Series D-Earth Sciences, 51(8), 1179-1193, 2008.

Sahu, L. K., Lal, S., Thouret, V., and Smit, H. G.: Seasonality of tropospheric ozone and water vapor over Delhi, India: a study based on MOZAIC measurement data, J. Atmos. Chem., 62(2), 151-174, 2009.

Sprenger, M. and Wernli, H.: A Northern Hemispheric climatology of cross-tropopause exchange for the ERA15 time period (19791993), J. Geophys. Res., 108, 8521, doi:10.1029/2002JD002636, 
2003.

Tulet, P., Suhre, K., Mari, C., Solmon, F., and Rosset, R.: Mixing of Boundary layer and upper tropospheric ozone during a deep convective event over Western Europe, Atmos. Environ., 36, 44914501, 2002.

Waters, J. W., Froidevaux, L., Harwood, R. S., Jarnot, R. F., Pickett, H. M., Read, W. G., Siegel, P. H., Cofield, R. E., Filipiak, M. J., Flower, D. A., Holden, J. R., Lau, G. K., Livesey, N. J., Manney, G. L., Pumphrey, H. C., Santee, M. L., Wu, D. L., Cuddy, D. T., Lay, R. R., Loo, M. S., Perun, V. S., Schwartz, M. J., Stek, P. C., Thurstans, R. P., Boyles, M. A., Chandra, S., Chavez, M. C., Chen, G.-S., Chudasama, B. V., Dodge, R., Fuller, R. A., Girard, M. A., Jiang, J. H., Jiang, Y., Knosp, B. W., LaBelle, R. C., Lam, J. C., Lee, K. A., Miller, D., Oswald, J. E., Patel, N. C., Pukala, D. M., Quintero, O., Scaff, D. M., Snyder, W. V., Tope, M. C., Wagner, P. A., and Walch, M. J.: The Earth Observing System Microwave Limb Sounder (EOS MLS) on the Aura satellite, IEEE Trans. Geosci. Rem. Sens., 44, 5, 2006.

Waugh, D. W., Hall, T. M., Randel, W. J., Rasch, P. J., Boville, B. A., Boering, K. A., Wofsy, S. C., Daube, B. C., Elkins, J. W., Fahey, D. W., Dutton, G. S., Volk, C. M., and Vohralik, P. F.: Three-dimensional simulations of long-lived tracers using winds from MACCM2, J. Geophys. Res., 102, 21493-21513, doi:10.1029/97JD00793, 1997.
Worden, J., Kulawik, S. S., Shepard, M., Clough, S., Worden, H., Bowman, K., and Goldman, A.: Predicted errors of Tropospheric Emission Spectrometer nadir retrievals from spectral window selection, J. Geophys. Res., 109, D09308, doi:10.1029/2004JD004522, 2004.

Worden, H. M., Bowman, K. W., Worden, J. R., Eldering, A., and Beer, R.: Satellite measurements of the clear-sky greenhouse effect from tropospheric ozone, Nat. Geosci., 1, 305-308, 2008.

Worden, J., Dylan, B., Jones, A., Liu, J., Parrington, M., Bowman, K., Stajner, I., Beer, R., Jiang, J., Thouret, V., Kulawik, S., Li, J. F., Verma, S., and Worden, H.: Observed vertical distribution of tropospheric ozone during the Asian summertime monsoon, J. Geophys. Res., 114, D13304, doi:10.1029/2008JD010560, 2009.

Zhang, Y., Takahashi, M., and Guo, L.: Analysis of the East Asian Subtropical Westerly Jet Simulated by CCSR/NIES/FRCGC Coupled Climate System Model, J. Meteoro. Soc. Jpn., 86, $257-$ 278, 2008. 